\title{
У Potilaiden ja läheisten kokemuksia lääkärien palliatiivisen hoidon ja saattohoidon osaamisesta
}

Palliatiivinen hoito on parantumattomasti sairaan potilaan ja hänen läheisensä aktiivista ja kokonaisvaltaista hoitoa. Palliatiivisen hoidon tarve tulee kasvamaan väestön ikääntyessä ja pitkäaikaissairauksien lisääntyessä. Palliatiivisen hoidon saannin turvaamiseksi lääkärillä tulee olla osaamista palliatiivisesta hoidosta ja saattohoidosta kaikilla terveydenhuollon tasoilla. Tutkimuksen tarkoituksena oli kuvailla potilaiden ja läheisten kokemuksia lääkärien osaamisesta palliatiivisessa hoidossa ja saattohoidossa.

Tutkimusaineisto kerätiin sähköisenä kyselynä ja tiedote kyselystä oli Palliatiivisen hoitotyön ja lääketieteen koulutuksen monialaisen ja työelämälähtöisen kehittämisen (EduPal) -hankkeen verkkosivulla. Avoimeen kysymykseen: Mitä mielestäsi jokaisen lääkärin tulee osata palliatiivisesta hoidosta ja saattohoidosta valmistuessaan? vastasi $4 \mathrm{I}$ potilasta ja läheistä. Aineisto analysoitiin induktiivisella sisällön analyysilla.

Potilaiden ja läheisten mukaan lääkärit tarvitsevat palliatiivisessa hoidossa ja saattohoidossa kivunhoidon osaamista. Lisäksi he tarvitsevat vuorovaikutusosaamista ja potilaslähtöisen hoidon osaamista. Potilaat ja läheiset arvoivat lääkärin tarvitsevan vahvaa kliinistä osaamista palliatiivisesta hoidosta ja saattohoidosta. Myös lääkäreiden kohtaamisosaamista sekä potilaan ja läheisten tukemisosaamista pidettiin tärkeänä.

Lääkärillä tulee olla laaja-alaista osaamista palliatiivisesta hoidosta ja saattohoidosta. Potilaiden ja läheisten kokemusten huomioiminen lääketieteen perusopetuksessa ja täydennyskoulutuksessa vahvistaa ja tukee kliinistä osaamista sekä potilaan hoidon laatua. Lääketieteen koulutukseen tulee lisätä vuorovaikutus- ja kohtaamistaitoja kehittävää opetusta sekä turvata kaikille lääketieteen opiskelijoille osaaminen palliatiivisen hoidon ja saattohoidon perusteista.

ASIASANAT: lääkäri, osaaminen, palliatiivinen hoito, potilas, läheinen

PIA MÄENPÄÄ, ANNAMARJA LAMMINMÄKI, PIRJO KAAKINEN, MINNA HÖKKÄ

\section{YDINASIAT}

- Palliatiivisen hoidon osaamisessa on kehitettävää hoidon eri tasoilla (A-C).

- Potilaat ja läheiset odottavat lääkärin hallitsevan kivunhoidon ja potilaslähtöisen hoidon sekä omaavan hyvät vuorovaikutustaidot.

- Valmistuvien lääkäreiden koulutuksessa tulee varmistaa riittävä kliininen-, vuorovaikutusja potilaslähtöisen hoidon osaaminen palliatiivisessa hoidossa.

- Tulevaisuudessa tulee tutkia, millaiset opetusmenetelmät ovat vaikuttavia palliatiivisen hoidon oppimiseen.

\section{JOHDANTO}

Palliatiivinen hoito on World Health Organization määritelmän mukaan parantumattomasti sairaan potilaan ja hänen läheistensä aktiivista, kokonaisvaltaista ja moniammatillista hoitoa, jolla pyritään lievittämään kärsimystä ja parantamaan elämänlaatua $(1,2)$. Saattohoito on viimeisten elinpäivien ja -viikkojen aikana tapahtuvaa kuolevan potilaan hoitoa $(3,4)$. Väestön ikääntyessä ja lääketieteen kehittyessä palliatiivista hoitoa ja saattohoitoa tarvitsevien potilaiden määrä lisääntyy. Palliatiivisen hoidon tarve kasvaa pitkäaikaissairauksien, kuten keuhko-, syöpä, sydän- tai munuaissairauksien, lisääntyessä $(1,5$.) 
Palliatiivinen hoito ja saattohoito tulee integroida osaksinykyistäterveydenhuoltojärjestelmää niiden saannin turvaamiseksi $(6,7)$. Suomessa on palliatiivisen hoidon ja saattohoidon palvelujen saatavuudessa vielä alueellista eriarvoisuutta. Puutteita on erityisesti erityistason palveluissa esimerkiksi kotisaattohoidon kattavuudessa (6.) Osaamisen vahvistaminen palliatiivisen hoidon kaikilla tasoilla; perustaso (A), erityistaso (B) ja vaativa erityistaso $(\mathrm{C})$, varmistaa palliatiivisen hoidon kehittämisen $(3,8)$. Perustaso sisältää kaikki terveyden- ja sosiaalihuollon yksiköt, jotka tarjoavat palveluja tai hoitoa elämän loppuun saakka mm. kotihoidon ja kotisairaanhoidon yksiköt, palvelutalot sekä sairaaloiden vuodeosastot, joissa hoidetaan muitakin kuin palliatiivisia potilaita. Perustaso sisältää myös A-tason yksiköt, joissa palliatiivista hoitoa on kehitetty ja toteutetaan osana yksikön toimintaa. Perustasolla terveydenhuollon ammattihenkilöiden tulee osata oirehoitoa, kuolevan potilaan ja hänen läheistensä huolenpitoa sekä psykososiaalisten ja henkisten tarpeiden arviointia (3.)

Henkilökunnan osaamisvaje on kuitenkin yksi merkittävä haaste palliatiivisessa hoidossa ja saattohoidossa. Valtakunnallisen kartoituksen mukaan palliatiiviseen hoitoon erikoistuneesta henkilökunnasta on vajetta Suomessa. Valtaosassa erityistason palliatiivisen hoidon ja saattohoidon yksiköistä toimii vain yksi koulutuksen saanut lääkäri, ja perustason yksiköissä erityispätevyyslääkäreitä ei juuri ole (6.) Myös WHO:n mukaan osaamisvaje on merkittävä puute palliatiivisessa hoidossa ja sen saatavuudessa. Suurimmalla osalla terveydenhuollon henkilökunnasta on vähän tai ei juuri ollenkaan osaamista palliatiivisesta hoidosta (9.)

Euroopan palliatiivisen hoidon yhdistys (EAPC) dokumenteissaan on korostanut, että lääkärillä tulee olla laaja-alaista palliatiivisen hoidon ja saattohoidon osaamista, jotta hän pystyy vastaamaan potilaan ja läheisen moninaisiin hoidon tarpeisiin $(5,10)$. Lääketieteen opetussuunnitelman tulee sisältää opetusta palliatiivisen hoidon perusteista, kipu ja oirehoidosta, psykososiaalisista ja hengellisistä näkökohdista, eettisistä ja juridisista kysymyksistä, kommunikointitaidoista sekä tiimityöskentelystä ja itsereflektiosta (5). Osaamisen kehittämiseksi ja potilaan laadukkaan hoidon turvaamiseksi on ensi arvoisen tärkeää, että jokainen yleislääkäri osaa pal- liatiivisen hoidon perusteet ja tarvittaessa konsultoi palliatiiviseen hoitoon erikoistuneita lääkäreitä. Palliatiivisen lääketieteen opetusta tulee kehittää ja palliatiivisen hoidon opetuksen tulee sisältyä lääketieteen opiskelijoiden koulutukseen osaamisen turvaamiseksi (2-6.) Riittävällä osaamisella voidaan turvata paremmin potilaiden asianmukainen palliatiivinen hoito ja tuki (3).

Sosiaali- ja terveysministeriön (STM:n) (3) ja EAPC:n $(5,10)$ dokumenttien lisäksi työelämän asiantuntijoiden (11) näkökulmasta tuodaan esille, että palliatiivisessa hoidossa lääkärillä tulee olla perustiedot potilaan fyysisistä, psyykkistä, sosiaalisista ja hengellisistä tarpeista sekä taitoa laatia ennakoiva hoitosuunnitelma potilaan hoidon tarpeiden pohjalta. Lääkäri tarvitsee tietoja ja taitoa ohjata potilasta ja läheistä, jotta potilas pystyy osallistumaan hoitoaan koskeviin päätöksiin lain suomin oikeuksin $(2,12,13)$. Lisäksi hoidossa korostuvat hyvät vuorovaikutustaidot potilaan ja läheisen kanssa $(5,10,11)$ sekä psyykkinen tukeminen (4,12). Moniammatillinen tiimityöskentely ja potilaan hoidon koordinaatio on raporteissa ja työelämän asiantuntijoiden kokemana noussut tärkeäksi osaksi osaamista palliatiivisessa ja saattohoidossa $(2,3,5,11,14)$. Lisäksi lääkärin on hyvä tunnistaa eettiset ja lainsäädännölliset periaatteet potilaan hoidossa $(5,10)$. Osa osaamista on taito huolehtia omasta työhyvinvoinnista sekä oman ammattitaidon kehittämisestä (10).

Lääkärien palliatiivista ja saattohoidon osaamista on tutkittu muun muassa moniammatillisen työelämäedustajiston näkökulmasta $(11,14)$, mutta potilaan ja läheisen kokemuksia palliatiivisesta hoidosta ja sen toteutuksesta on tutkittu vähän (15). Potilaiden ja läheisten tarpeiden mukainen hoito edellyttää myös heidän näkökulmansa selvittämistä. Tällä tutkimuksella halutaan lisätä tietoa lääkärien osaamisesta nimenomaan potilaan ja läheisen näkökulmasta.

\section{TUTKIMUKSEN TARKOITUS JA TUTKIMUSTEHTÄVÄ}

Tutkimuksen tarkoituksena oli kuvailla potilaiden ja läheisten kokemuksia lääkärien palliatiivisen hoidon ja saattohoidon osaamisesta. Tavoitteena on tuottaa tietoa lääketieteen koulutuksen kehittämiseksi, jotta palliatiivisen hoidon laatua voidaan parantaa.

Tutkimustehtävä: Millaista osaamista lääkärillä tulee olla palliatiivisesta hoidosta ja saattohoidosta potilaan ja läheisen kokemana? 
MENETELMÄT

\section{TUTKIMUKSEN AINEISTON KERUU JA OSALLISTUJAT}

Tutkimusaineisto kerättiin sähköisenä Webropolkyselynä syys-lokakuussa vuonna 2018. Linkki kyselyyn oli Palliatiivisen hoitotyön ja lääketieteen koulutuksen monialaisen ja työelämälähtöisen kehittämisen (EduPal) hankkeen Internet sivuilla. Avoimeen kysymykseen "Millaista osaamista lääkärillä tulee olla palliatiivisesta hoidosta ja saattohoidosta?" - pyydettiin vastaamaan henkilöitä, jotka kokivat, että heillä on näkemyksiä lääkärien palliatiivisen hoidon tai saattohoidon osaamisesta. Avoimeen kysymykseen vastasi 79 henkilöä, joista 41 henkilöä oli potilaita $(n=10)$ ja läheisiä $(\mathrm{n}=31)$. Tähän tutkimukseen otettiin mukaan potilaiden ja läheisten vastaukset. Vastaajien ikä vaihteli $28-78$ vuoden välillä. Vastaajista suurin osa oli naisia $90 \%$ ja neljäsosa vastaajista oli eläkkeellä.

\section{AINEISTON ANALYYSI}

Aineisto analysoitiin induktiivisella sisällönanalyysillä $(16,17)$. Excel-tiedostomuotoinen teksti muodostui lyhyistä, toteavista ilmauksista ja ne siirrettiin Word -tekstimuotoon sekä vastaukset koodattiin, joka mahdollisti palaamisen alkuperäiseen aineistoon. Aineiston analyysi aloitetiin lukemalla tekstiä useita kertoja, jonka jälkeen tekstistä etsittiin ajatuskokonaisuuksia ja lauseita, jotka vastasivat tutkimustehtävään. Ajatuskokonaisuudet ja lauseet pelkistettiin, ja pelkistyksiä muodostui 170. Tämän jälkeen pelkistetyistä ilmauksista etsittiin samankaltaisuuksia, ja samankaltaiset pelkistetyt ilmaukset ryhmiteltiin alaluokkiin $(n=35)$ ja nimettiin sisällön mukaisesti. Alaluokkia yhdisteltiin yläluokiksi $(\mathrm{n}=14)$ ja niille annettiin sisältöä kuvaavat nimet. Yläluokkia yhdisteltiin pääluokiksi $(n=6)$ ja nimettiin. Pääluokista muodostui yhdistävä luokka lääkärin osaaminen palliatiivisessa hoidossa ja saattohoidossa. Esimerkki aineiston analyysistä taulukossa 1.

Taulukko 1. Esimerkki analyysin etenemisestä yksilöllinen kivun arviointi.

\begin{tabular}{|c|c|c|c|}
\hline Alkuperäisilmaisu & Pelkistys & Alaluokka & Yläluokka \\
\hline $\begin{array}{l}\text { - kivun tunnistaminen (69) * } \\
\text { - ei suoraan kivuissa verrata } \\
\text { "tämä nyt on tätä, tässä } \\
\text { taudissa", vaan kuunnellaan } \\
(39) *\end{array}$ & $\begin{array}{l}\text { - kivun tunnistaminen (69) * } \\
\text { - aito kuuntelu kipujen suhteen, } \\
\text { ei yleistetä (39) * }\end{array}$ & $\begin{array}{l}\text { kivun yksilöllinen } \\
\text { tunnistaminen }\end{array}$ & $\begin{array}{l}\text { yksilöllinen kivun } \\
\text { arviointi }\end{array}$ \\
\hline $\begin{array}{l}\text { - toimenpiteissä huomioitava } \\
\text { yksilön kivut }(39) *\end{array}$ & $\begin{array}{l}\text { - toimenpiteissä huomioitava } \\
\text { yksilön kivut }(39)^{*}\end{array}$ & $\begin{array}{l}\text { toimenpidekivun } \\
\text { huomiointi }\end{array}$ & \\
\hline
\end{tabular}

* numero viittaa vastaajaan

\section{TULOKSET}

Lääkärin tarvitsemaa osaamista palliatiivisesta hoidosta ja saattohoidosta kuvasivat seuraavat pääluokat: kivunhoidon osaaminen, vuorovaikutusosaaminen, potilaslähtöisen hoidon osaaminen, palliatiivisen hoidon ja saattohoidon kliininen osaaminen, kohtaamisosaaminen sekä potilaan ja läheisten tukemisosaaminen (Taulukko 2).

Kivunhoidon osaaminen sisälsi yksilöllisen kivun arvioinnin ja ohjauksen sekä riittävän kivunhoidon. Yksilöllisessä kivun arvioinnissa on ensiarvoisen tärkeää tunnistaa potilaan kipu ja yksilölliset erot toimenpidekivun kokemuksissa. Yksilöllistä kivunhoitoa helpottavat lääkärin taito kuunnella potilaan kertomusta kivusta sekä taito tunnistaa kivusta johtuvat oireet. Riittävä kivunhoito sisälsi potilaan kivuttomuuden var- mistamisen sekä lääkeannostelijan käyttöönoton potilaalle riittävän ajoissa. Riittävä kivunhoito tulee olla osa lääkärin perusosaamista.

Läheinen: "Oikeanlainen kivunhoito. Lääkärin pitäisi lisäksi tietää, mikä on se oikea kivunhoidon määrä, millä mennään. Ei tällaista, että potilas joutuu kärsimään kivuista viimeisinä hetkinään.”

Vuorovaikutusosaaminen sisälsi kommunikoinnin potilaan ja läheisten kanssa sekä asianmukaisen käyttäytymisen. Kommunikointi ilmenee taitona kuunnella potilasta ja läheistä sekä dialogisena keskusteluna heidän kanssaan. Vuorovaikutustilanteissa käytettävä kieli tulee olla yleistajuista, jolloin potilaalla ja läheisillä on mahdollisuus ymmärtää keskustelun sisältö. 
Taulukko 2. Lääkärin osaaminen palliatiivisessa hoidossa ja saattohoidossa

\begin{tabular}{lll}
\hline Alaluokka & Yläluokka & Pääluokka \\
\hline $\begin{array}{l}\text { Kivun yksilöllinen tunnistaminen } \\
\text { Toimenpidekivun huomiointi }\end{array}$ & $\begin{array}{l}\text { Yksilöllinen kivun arviointi ja } \\
\text { ohjaus }\end{array}$ & Kivunhoidon osaaminen \\
$\begin{array}{l}\text { Kivunhoidon ohjaus } \\
\begin{array}{l}\text { Lääkeannostelijan käyttö } \\
\text { Kivunhoito osana lääkärin työtä }\end{array}\end{array}$ & Riittävä kivunhoito \\
\hline $\begin{array}{l}\text { Potilaan ja läheisen kuuntelu } \\
\text { Yialoginen keskustelu }\end{array}$ & $\begin{array}{l}\text { Kommunikointi potilaan ja } \\
\text { läheisten kanssa }\end{array}$ & \\
$\begin{array}{l}\text { Empaattisuus } \\
\text { Kunnioittava käyttäytyminen }\end{array}$ & Asianmukainen käyttäytyminen & Vuorovaikutusosaaminen \\
\hline $\begin{array}{l}\text { Yksilöllinen hoito } \\
\text { Yhteisöllisyyden huomiointi } \\
\text { Potilas elämänsä asiantuntijana }\end{array}$ & $\begin{array}{l}\text { Potilaan asiantuntijuuden } \\
\text { huomiointi hoidossa }\end{array}$ & Potilaslähtöisen hoidon \\
\hline
\end{tabular}

Ymmärrys palliatiivisesta ja

saattohoidosta

Taito toimia palliatiivisessa ja Asiantuntijuus palliatiivisessa ja

saattohoidossa

Tietoa palliatiivisesta ja

saattohoidosta

Tietoa kuntoutuksesta

Hyvä lääketieteellinen hoito

Palliatiivisen hoidon ja saattohoidon

kliininen osaaminen

Potilaan ja läheisten ohjaus

Vaikeiden asioiden esille ottaminen

Ohjaus palliatiivisessa ja

saattohoidossa

Saattohoitopäätöksen

tekeminen

Hoitosuunnitelman päivittäminen

Elämän loppuvaiheen

hoitosuunnitelman

laatiminen

Huomaavainen kohtaaminen

Rinnalla kulkemisen taito

Rohkeus kohdata

Potilaan ja läheisen kohtaaminen

Läsnä potilaan ja läheisen rinnalla

Riittävästi aikaa potilaalle

Kiireetön läsnäolo

Kohtaamisosaaminen

ja läheiselle

Rohkeus käsitellä omia tunteita

Itsereflektiotaitoa

Läheisten mukaanotto

Läheisten tukeminen

Psyykkinen tuki

Henkinen tuki

Kärsimyksen lievittäminen

Potilaan ja läheisten toiveet

hoidosta
Yhteistyö läheisten kanssa

Potilaan ja läheisten

Psyykkisen ja henkisen

hyvinvoinnin tukeminen tukemisosaaminen 
Asianmukainen käyttäytyminen ilmeni empaattisuutena ja kunnioittava käyttäytymisenä vuorovaikutustilanteissa. Empaattisuus vuorovaikutustilanteissa näyttäytyi myötätunnon ja empatian osoittamisena keskustelun aikana. Lääkärin kunnioittava käyttäytyminen on potilaan ja läheisten kunnioittamista ja hyviä käytöstapoja heitä kohtaan. "Ei suoraan kivuissa verrata "tämä nyt on tätä, tässä taudissa", vaan kuunnellaan ja pubutaan sama asia kauniisti" (läheinen).

Potilaslähtöisen hoito sisälsi potilaan asiantuntijuuden huomioimisen hoidossa. Tämä ilmeni potilaan yksilöllisenä hoitona sekä potilaan yhteisöllisyyden ja hänen oman elämänsä asiantuntijuuden huomiointina. Yksilöllinen hoito tuli esille lääkärin taidoissa paneutua potilaan oireisiin, huomioida potilaan henkilökohtaisia tottumuksia, tapoja ja rajoitteita sekä yksilöityinä hoitokäytänteinä. Potilaslähtöinen hoito edellyttää myös ymmärrystä siitä, että potilas on osa yhteisöä, jossa hän elää. Potilaslähtöisessä hoidossa potilasta arvostetaan oman elämänsä asiantuntijana ja häntä kohdellaan yksilönä, ei pelkkänä diagnoosina. "Ymmärrys siitä, että asiakas on osa ybteisöä ja että hänellä on ollut elämää ennen sairautta, tapoja, tottumuksia, ibmisiä" (läheinen)

Palliatiivisen hoidon ja saattohoidon kliininen osaaminen sisälsi asiantuntijuuden palliatiivisessa hoidossa ja saattohoidossa, ohjauksen palliatiivisesta hoidosta ja saattohoidosta sekä elämän loppuvaiheen hoitosuunnitelman laatimisen.

Palliatiivisessa hoidossa ja saattohoidossa asiantuntijana toimiminen edellyttää ymmärrystä ja tietoa palliatiivisesta hoidosta, saattohoidosta ja kuntoutuksesta sekä taitoa toimia. Lääkärin tulee ymmärtää palliatiivisen ja saattohoidon erot sekä oma rooli ja vastuut hoidossa. Hänellä tulee olla palliatiivisen hoidon ja saattohoidon vaatimaa erikoisosaamista ja näyttöön perustuvaa tietoa hoitovaihtoehdoista ja kuntoutuksesta sekä tietoa toteuttaa potilaan hyvää lääketieteellistä hoitoa.

Ohjaus palliatiivisesta ja saattohoidosta sisälsi potilaan ja läheisten ohjauksen sekä vaikeiden asioiden esille ottamisen. Potilaat ja läheiset haluavat ohjauksessa informaatiota palvelujärjestelmästä ja vertaistuesta sekä, mistä he saavat luotettavaa lisätietoa sairaudestaan ja hoidostaan. Vaikeiden asioiden esille ottaminen sisälsi keskustelua lähestyvästä kuolemasta, potilaan lop- puvaiheen oireista ja elvytyskiellosta. "Kyky ottaa puheeksi lähestyvästä kuolemasta keskusteleminen" (läheinen).

Läheinen: "Selvittää omaiselle, millainen on todennäköisesti loppuvaihe ennen esim. syöpää sairastavan kuolemaa. Mitä oireita/käytöstä odotettavissa ja mitä se vaatii omaiselta etenkin, jos potilas on kotisaattohoidossa.

Elämän loppuvaiheen hoitosuunnitelman laatimiseen sisältyi potilaan saattohoitopäätöksen tekeminen sekä hoitosuunnitelman tarkistaminen ja päivittäminen. Läheiset haluavat tietää saattohoitomahdollisuuksista ja saattohoitoon siirtymisestä ajoissa, jolloin potilaalle turhista toimenpiteistä voidaan luopua. Hoitosuunnitelman päivittäminen sisälsi myös hoitotahdon läpikäymisen potilaan kanssa. "Ammattitaitoa arvioida, milloin lääketieteelliset toimenpiteet ja hoidot eivät enää auta eli palliatiiviseen ja saattohoitoon siirtymisen oikea ajoitus" (potilas).

Kohtaamisosaaminen ilmeni taitona kulkea potilaan ja läheisen rinnalla, kiireettömänä läsnäolona ja itsereflektiotaitoina. Rinnalla kulkemisen taito välittyi huomaavaisena kohtaamisena, jossa potilasta ja läheistä kunnioitettiin. Kohtaamisen tulee olla kiireetöntä läsnäoloa, ajan antamista potilaalle ja läheiselle. Merkityksellistä on olla läsnä ja tavoitettavissa elämän loppuvaiheessa. "Miten olla läsnä kuolevan potilaan ja omaisten rinnalla elämän viime päivinä" (läheinen).

Itsereflektiotaidot ilmenivät lääkärin omien tunteiden käsittelynä. Lääkärillä tulee olla rohkeutta kohdata myös omat tunteensa. "Kyky ja tahto käsitellä itsessä heränneitä tunteita ja kokemuksia" (läheinen)

Potilaan ja läheisen tukemisosaaminen ilmeni yhteistyönä läheisten kanssa sekä psyykkisen ja henkisen hyvinvoinnin tukemisena. Yhteistyö on läheisten mukaanottoa hoitopäätösten tekemiseen ja heidän rohkaisuaan osallistua hoitoon. Lisäksi se on läheisten tukemista. Psyykkinen ja henkisen hyvinvoinnin tukeminen tuli esille potilaan ahdistuksen ja pelkojen kohtaamisena, henkisenä tukena ja kärsimysten lievittämisenä. Potilaan ja läheisten hyvinvointia edisti myös heidän toiveidensa kunnioittaminen elämän loppuvaiheessa. "Mielestäni lääkärin tehtävä on selvittää sairaan loppuajan toiveet hoidosta" (läheinen). 


\section{POHDINTA}

\section{TULOSTEN TARKASTELUA}

Tämän tutkimuksen tarkoituksena oli kuvailla potilaiden ja läheisten kokemuksia lääkärien palliatiivisen hoidon ja saattohoidon osaamisesta. Tulosten mukaan potilaat ja läheiset odottavat lääkäriltä laaja-alaista osaamista palliatiivisessa hoidossa ja saattohoidossa. Näitä ovat kivunhoidon osaaminen, vuorovaikutusosaaminen, potilaslähtöisen hoidon osaaminen, palliatiivisen hoidon ja saattohoidon kliininen osaaminen, kohtaamisosaaminen sekä potilaan ja läheisten tukemisosaaminen.

Vastaajat pitävät tärkeänä asiana hyvää kivunhoitoa. Heidän mielestään on tärkeää, että elämän loppuvaiheessa potilas on mahdollisimman kivuton. Kipu on yleinen oire monissa kuolemaan johtavissa sairauksissa (4). Potilailla ja läheisillä on pelkoa mahdollisista kivuista. Kipu on kuitenkin oire, joka on helposti tunnistettavissa (18.) Kivunhoito vaatii laaja-alaista osaamista niin lääkkeellisistä kuin lääkkeettömistäkin kivunhallintakeinoista (8).

Vastaajien mukaan lääkärin on tärkeä kuunnella potilasta ja läheistä sekä keskustella heidän kanssaan. Käytetyn kielen tulee olla ymmärrettävää ja yleistajuista. Vastaajat odottavat lääkäriltä myötätunnon ja empatian osoittamista. Potilaan sairastaessa vakavasti hän tarvitsee kahdenkeskistä keskusteluaikaa lääkärin kanssa luottamuksen ja turvallisuuden synnyttämiseksi. Dialoginen keskustelu ja aito kuuntelu on oleellinen osa potilaan hoitoa $(19,20$.$) Myös terveydenhuollon$ ammattilaisten mukaan lääkärillä tulee olla sosiaalisia vuorovaikutustaitoja (11). Lääkärin rehellisyys, herkkyys, myötätunto, inhimillisyys ja lempeys sekä kokemus alalta mahdollistavat myös hyvää palliatiivista hoitoa $(5,20)$.

Vastaajien mukaan lääkärillä tulee olla osaamista oikea-aikaisen saattohoitopäätöksen tekemisestä sekä hoitosuunnitelman päivittämisestä ja siitä tiedottamisesta. Tämä tulos tukee myös aiemman tutkimuksen tulosta, jossa ennakoivan hoitosuunnitelman tekemisen osaaminen sekä lääkärin päätöksentekotaidot olivat keskeisiä kompetenssialueita (11). Tärkeää on ottaa ajoissa puheeksi potilaan ja läheisen kanssa palliatiivinen hoito, saattohoitopäätös ja hoitotahto $(2,3,21$.) Myös tässä tutkimuksessa vastaajat odottivat, että lääkäri ottaa puheeksi elämän loppuvaiheen hoidon ja kuoleman heidän kanssaan yhteisymmärryksessä.

Tulosten mukaan potilaat ja läheiset haluavat tietoa sairaudesta ja hoidosta sekä osallistua hoitoon ja hoitopäätösten tekoon. Myös muiden tutkimusten mukaan hoidon suunnitteluun ja toteutukseen osallistuminen on tärkeää sairauden kaikissa vaiheissa $(2,22,23)$. Potilaiden ja läheisten on tärkeää saada riittävästi tietoja tämän mahdollistumiseksi $(2,23)$. Mutta viivästyneiden päätösten ja hoitokeskustelun puutteen takia osallistuminen ei aina onnistu (24). Vastaajille oli tärkeää, että lääkärillä on heille aikaa, hän on tavoitettavissa ja kohtaaminen heitä kohtaan on kunnioittavaa. Hyvä kommunikointi on ajan antamista, läsnäoloa, toisen aitoa kuuntelua ja ymmärtämistä, kipuihin eläytymistä, rehellisen tiedon antamista ja lasten huomiointia (2).

Tässä tutkimuksessa tuli esille, että potilailla ja läheisillä on ahdistusta ja pelkoja, joihin he toivovat lääkäriltä tukea. Heillä on myös toiveita elämän loppuvaiheen hoidon suhteen, joita he odottavat lääkärin kunnioittavan. Myös läheiset odottivat saavansa psyykkistä tukea lääkäriltä. Potilaan vakava sairaus aiheuttaa kärsimystä koko perheelle, joten läheisten huomioiminen on osa kokonaisvaltaista palliatiivista hoitoa (4). Potilaan hyvä hoito sekä mahdollisuus ilmaista huolia ja tunteita sekä saada niihin tukea, auttaa selviytymään surusta ja menetyksistä (2).

Ihmiset toivovat hyvää elämän loppuvaiheen hoitoa ja sitä, että voivat olla tutussa asuinympäristössä mahdollisimman pitkään, jopa kuolla kotona. Vaikeat oireet, tuen puute ja turvattomuus voivat kuitenkin johtaa toistuviin päivystyskäynteihin, jos palliatiivisesta hoidosta ei ole huolehdittu. Nämä käynnit lisäävät myös yhteiskunnan kustannuksia. Terveydenhuollon ammattihenkilöiden osaamista voidaan vahvistaa yhdenmukaistamalla perus- ja erikoistumiskoulutusta, sillä osaamista tarvitaan hoivayksiköistä erikoissairaanhoitoon. Osaamista kehittämällä voidaan parantaa myös laadukkaan palliatiivisen hoidon saatavuutta, jotta kaikilla potilailla ja läheisillä olisi mahdollisuus saada asianmukaista hoitoa ja tukea elämän loppuvaiheessa (6.) Tämä tutkimus osaltaan lisää tietämystä siitä, millaista osaamista lääkärillä tulee olla koulutuksen kehittämiseksi. 


\section{TUTKIMUKSEN EETTISYYS JA LUOTETTAVUUS}

Tutkimuksessa noudatettiin hyviä tieteellisiä käytänteitä. Ennen tutkimuksen aineiston keruuta EduPal-hankkeen tutkimuskokonaisuus tarkistettiin eettisen toimikunnan puolesta, jonka lopputuloksena oli, että eettisen toimikunnan lausuntoa ei tarvita. Vastaajat saivat tietoa tutkimuksesta, sen tarkoituksesta ja tavoitteista EduPal hankkeen Internetsivulta. Kyselyn ensimmäisellä sivulla oli tiedote tutkimuksesta, jossa kerrottiin tutkimukseen osallistumisen olevan vapaaehtoista, vastaamisen tapahtuvan anonyymisti sekä oikeudesta keskeyttää kysely missä vaiheessa tahansa (25.) Kyselyssä oli pakko vastata tietoinen suostumus -kysymykseen joko kyllä tai ei (26). Yksittäisiä vastaajia ei tutkimuksen tuloksista pysty tunnistamaan (27) ja aineisto säilytettiin tietokoneella salasanalla suojattuna sekä aineisto hävitetään tulosten julkaisun ja EduPal-hankkeen päättymisen jälkeen (2016/679).

Tutkimuksen luotettavuutta arvioitiin uskottavuuden, siirrettävyyden ja vahvistettavuuden kriteereillä $(28,29)$. Uskottavuutta lisää vastaajien kokemukset tutkittavasta ilmiöstä sekä tutkijan ennakko-oletusten syrjäyttäminen analyysiä tehtäessä. Lisäksi uskottavuutta lisää kolmen tutkijan osallistuminen aineiston analyysiin niin, että ensimmäinen tutkija teki analyysin ja kaksi muuta kommentoivat itsenäisesti analyysiprosessin etenemistä. Tutkijat keskustelivat vielä yhdessä havaintojen analyysista ja tulkinnasta, jotta luokitukset saatiin mielekkäiksi, niissä ei ollut päällekkäisyyksiä ja analyysi oli looginen. Uskottavuutta voi heikentää se, että tutkijoiden tulkinta ei vastaa tutkittavien näkemyksiä. Siirrettävyyttä voi heikentää se, ettei vastaajien taustatietoja kerätty tässä tutkimuksessa tarkasti. Tutkimuksen alussa vastaajilta kysyttiin, ovatko he potilaita vai läheisiä, joten tämä tieto perustui vastaajan omaan ilmoitukseen. Vahvistettavuuden lisäämiseksi analyysiprosessi on pyritty kuvaamaan mahdollisimman tarkasti ja lisäämään alkuperäisilmaisuja (16).

\section{JOHTOPÄÄTÖKSET}

Lääkärillä tulee olla laaja-alaista osaamista palliatiivisesta hoidosta ja saattohoidosta. Tässä tutkimuksessa kohtaamiseen ja vuorovaikutukseen liittyvä osaaminen korostui potilaiden ja läheisten kokemana. Lääketieteen koulutukseen tulee lisätä vuorovaikutus- ja kohtaamistaitoja kehittävää opetusta sekä turvata kaikille lääketieteen opiskelijoille osaaminen palliatiivisen hoidon ja saattohoidon perusteista. Potilaiden ja läheisten kokemukset lääkärin osaamisesta tulee huomioida lääketieteen perusopetuksen ja täydennyskoulutuksen kehittämisessä. Tämä vahvistaa ja tukee lääkäreiden laaja-alaista osaamista sekä potilaan hoidon laatua.

\section{RAHOITTAJAT:}

Tutkimuksen tekemistä on tukenut EduPal-projekti, joka on saanut rahoitusta opetus- ja kulttuuriministeriöltä (päätös 29.3.2018 OKM/ 258/ 523/2017). Rahoittajalla ei ole roolia tämän tutkimuksen suunnittelussa tai artikkelin käsikirjoituksessa.

\section{KIRJOITTAJIEN KONTRIBUUTIOT:}

Mäenpää, Kaakinen ja Hökkä ovat suunnitelleet tutkimuksen. Hökkä on toteuttanut aineiston keruun. Mäenpää, Kaakinen ja Hökkä ovat analysoineet aineiston. Mäenpää, Kaakinen ja Hökkä ovat kirjoittaneet käsikirjoituksen. Lamminmäki, Kaakinen ja Hökkä ovat kommentoineet käsikirjoitusta.

\footnotetext{
Mäenpää, P., Lamminmäki, A., Kaakinen, P., Hökkä, M. Patients' and closed ones' experiences on competences required from physicians in palliative care and end-of life care. Sosiaalilääketieteellinen aikakauslehti - Journal of Social Medicine 202 I: 58: 182-190.
}

Palliative care is active and holistic care for incurably ill patients and their closed ones. The need for palliative care will increase as the population ages and the amount of long-term illnesses increase. The purpose of the study was to describe the experiences of patients and their closed ones physicians' competence in palliative care and endof-life care.
The research data was collected as an electronic survey and a newsletter on the website of Developing palliative nursing and medical education-EduPal -project. An open question: What do you think every physician should know about palliative care and end-of-life care when graduating? responded to 41 patients and closed ones. 
The data was analyzed using inductive content analysis.

According to patients and their closed ones, the physicians need competence in pain management in palliative care and end-of-life care. In addition, they need interaction skills and competence in patient-centred care. Patients and closed ones appreciated the physicians need for strong clinical competence in palliative care and end-oflife care. The competence in empathetic meeting of the patient and the competence in supporting of patients and closed ones were also considered important.

The physician must have extensive competence in palliative care and end-of-life care. Con- sidering patients' and closed ones' experiences in basic and continuing medical education strengthens and supports clinical competence and the quality of patient care. Medical education must be supplemented with a curriculum that develops interaction and communication skills, and all medical students must be provided with knowledge of the basics of palliative care and end-of-life care.

Keywords: physician, competence, palliative care, patient, closed ones

Saapunut (02.02.2021)

Hyväksytty (27.04.2021)

\section{LÄHTEET}

(1) WHO. Global Atlas of Palliative Care at the End of Life. January 2014. Worldwide Palliative Care Alliance and World Health organization. Luettu 23.4.2020. https://www.who.int/nmh/ Global_Atlas_of_Palliative_Care.pdf

(2) Council of Europe. Recommendation Rec 24 of the Committee of Ministers to member states on the organization of palliative care. Adopted by the Committee of Ministers on 12 November 2003 at the 860th meeting of the Ministers' Deputies. 2003. Luettu 23.4.2020. https://www. coe.int/t/dg3/health/Source/Rec(2003)24_en.pdf.

(3) Saarto T, Asiantuntijatyöryhmä. Palliatiivisen hoidon ja saattohoidon järjestäminen. Sosiaali- ja terveysministeriö Helsinki 2017. Luettu 3.6.2020. http://urn.fi/URN:ISBN:978-952-00-3896-0.

(4) Käypä hoito -suositus Palliatiivinen hoito ja saattohoito. Suomalaisen Lääkäriseuran Duodecimin ja Käypä hoito -johtoryhmän asettama työryhmä 2019. Luettu 23.4.2020. https://www.kaypahoito.fi/hoi50063.

(5) EAPC. Recommendations of the European Association for Palliative Care (EAPC) for the development of undergraduate curricula in palliative medicine at European medical schools. Report of the EAPC steering group on medical education and training in palliative care. European association for palliative care 2013. Luettu 20.4.2020. https:// dadun.unav.edu/bitstream/10171/34516/1/ Recommendations $\% 20$ of $\% 20$ the $\% 20$ EAPC\%20for\%20the\%20Development $\% 20$ of $\% 20$ Undergraduate $\% 20$ Curricula $\% 20$ in $\% 20$ Palliative $\% 20$ Medicine $\% 20$ At $\% 20$ European\%20Medical\%20Schools.pdf

(6) Saarto T, Finne-Soveri H, Asiantuntiatyöryhmä. Palliatiivisen hoidon ja saattohoidon tila Suomessa. Alueellinen kartoitus ja ehdotuksia laadun ja saatavuuden parantamiseksi. Sosiaali-

ja terveysministeriö 2019. Luettu 3.6.2020. http://urn.fi/URN:ISBN:978-952-00-4041-3

(7) Thrane S. Online palliative and end-of-life care education for undergraduate nurses. J Prof Nurs. 2020;36(1):42-46.

(8) Käypä hoito -suositus Palliatiivinen hoito osana terveydenhuoltojärjestelmää. Suomalaisen Lääkäriseuran Duodecimin ja Käypä hoito -johtoryhmän asettama työryhmä 2019. Luettu 23.4.2020. https://www.kaypahoito.fi/nix02562.

(9) Paal P, Brandstötter C, Lorenzl S, ym. Postgraduate palliative care education for all healthcare providers in Europe: Results from an EAPC survey. Palliat Support Care 2019; 17(5): 495-506.

(10) Gamondi C, Larkin P, Payne S. Core competencies in palliative care: an EAPC White Paper on palliative care education - part 2 . Eur J palliat care 2013; 20(3):140-145.

(11) Melender H-L, Hökkä M, Saarto T, ym. The required competencies of physicians within palliative care from the perspectives of multiprofessional expert groups: a qualitative study. BMJ Palliat care 2020; 65. Luettu 24.4.2021. https://bmcpalliatcare.biomedcentral.com/ articles/10.1186/s12904-020-00566-5.

(12) Gamondi C, Larkin P, Payne S. Core competencies in palliative care: an EAPC White Paper on palliative care education - part 1 . Eur J palliat care 2013; 20(2):86-91.

(13) Laki potilaan asemasta ja oikeuksista 17.8.1992/785. https://finlex.fi/fi/laki/ ajantasa/1992/19920785

(14) Lipponen V, Karvinen I. Palliatiivista ja saattohoitoa koskevat koulutustarpeet hoitohenkilöstön ja lääkäreiden kuvaamina. Gerontologia 2015; 29(3):152-163. 
(15) Hansson R, Nicholson E, Muldrew D, ym. International palliative care research priorities: A systematic review. BMC Palliat Care 2020; 19:16. https://doi.org/10.1186/s12904-020-0520-8

(16) Elo S, Kyngäs H. The qualitative content analysis process. J Ad Nurs. 2008; 1(62): 107-115.

(17) Kyngäs H, Mikkonen K, Kääriäinen M. The application of content analysis in nursing science research. Springer International Publishing, Cham. 2019.

(18) Hänninen J. Kuolevan kipu. Sic! Lääketietoa Fimeasta 2015;5(4): 36-37.

(19) Kaleva-Kerola J. Potilaan ja lääkärin kohtaaminen on ikiaikainen taitolaji. Duodecim 2020; 136(1): 108-109. https://www. terveysportti.fi/xmedia/duo/duo15319.pdf.

(20) Masel E, Kitta A, Huber P, ym. What makes a good palliative care physician? a qualitative study about the patient's expectations and needs when being admitted to a palliative care. Unit. PLoS ONE 2016;11(7). https://journals. plos.org/plosone/article/file? id=10.1371/journal. pone.0158830\&type $=$ printable

(21) Radbruch L, Payne S. White paper on standards and norms for hospice and palliative care in Europe: part 2. Eur J Palliat Care 2010;17(1): 22-33.

(22) Kaasa S, Loge JH, Aapro M. ym. Integration of oncology and palliative care: A Lancet Oncology Commission. Lancet Oncol. 2018;19(11): 588653.

(23) Radbruch L, Payne. S. White paper on standards and norms for hospice and palliative care in Europe: part 1. Eur J Palliat Care 2009; 16(6): 278-289.

(24) Belanger E, Rodrigues C, Groleau D. Shared decision-making in palliative care: A systematic mixed studies review using narrative synthesis. Palliat. Med. 2011;25: 242-61.
(25) TENK Tutkimuseettinen neuvottelukunta. Hyvä tieteellinen käytäntö ja sen loukkausepäilyjen käsitteleminen Suomessa. 2012. Luettu 4.5.2019. http://www.tenk.fi/sites/tenk.fi/files/HTK_ ohje_2012.pdf.

(26) Gray JR, Grove SK, Surtherland S. Burns and Grove's the practice of nursing research. Appraisal, synthesis, and generation of evidence. 8th edition. St. Louis Missouri: Elsevier. 2017.

(27) Tietosuojalaki 5.12.2018/1050. https://www.finlex.fi/fi/laki/ ajantasa/2018/20181050

(28) Lincoln YS, Guba EG. Naturalistic Inquiry. Sage Publications, California. 1985.

(29) Elo S, Kääriäinen M, Kanste O, ym. Qualitative content analysis: a focus on trustworthiness. SAGE Open 2014;4. doi: $10.1177 / 2158244014522633$.

\section{PiA MäENPäÄ}

TtM, lehtori

Oulun Ammattikorkeakoulu

Hoitoalat

\section{ANNAMARJA LAMMINMÄKI}

LT, erikoislääkäri

Itä-Suomen Yliopisto ja KYS Syöpäkeskus

\section{PirJo KAAKINEN}

TtT, yliopiston lehtori

Oulun yliopisto

Hoitotieteen ja terveyshallintotieteen tutkimusyksikkö

\section{MinNA HÖKKä}

TtM, koulutusjohtaja, projektipäällikkö

Kajaanin ammattikorkeakoulu 